\title{
Development and validation of a quantitative qPCR assay for detecting Natterjack toad (Epidalea calamita) eDNA samples
}

\author{
Marina Reyne $^{1}$ (D) Amanda M. Naaum ${ }^{1,3} \cdot$ Ferdia Marnell $^{2} \cdot$ Neil Reid $^{1,3}$ (D) $\cdot$ Sarah J. Helyar ${ }^{1,3}$ (D)
}

Received: 2 December 2020 / Accepted: 15 February 2021 / Published online: 4 March 2021

(c) The Author(s) 2021

\begin{abstract}
The Natterjack toad (Epidalea calamita) is the rarest amphibian species in Ireland, regionally Red-Listed as Endangered. We applied an eDNA approach to detect species presence in breeding pond water samples. We developed a species-specific qPCR assay targeting the cytochrome $c$ oxidase subunit I (COI). The assay was tested in silico, in vitro (DNA extracted from tissue) and in vivo (DNA extracted from water samples). Water samples were collected from five ponds with known Natterjack toad presence or absence to validate the sensitivity and specificity of the assay. The assay was shown to be highly specific to the Natterjack toad and tested positive only against toad tissue samples and eDNA samples from ponds with known species presence. We believe this method can be used for rapid assessment of species occurrence.
\end{abstract}

Keywords Cytochrome oxidase I · Epidalea calamita $\cdot$ Environmental DNA · Quantitative PCR

Species distribution is among the most basic and important data in ecology and conservation of wild populations, but often obtaining robust distribution records can be challenging (Mazerolle et al. 2007). Recent developments in molecular methods can offer a solution through non-invasive genetic monitoring, where DNA can be extracted from the environment (e.g. water, soil) to obtain targeted presence-absence data (Deiner et al. 2017). Environmental DNA (eDNA) analysis has already demonstrated that it is a powerful biodiversity monitoring tool with diverse applications in conservation management. This technique is especially useful for monitoring elusive species susceptible to disturbance (Laramie et al. 2015; Ma et al. 2016; Dougherty et al. 2016; Vörös et al. 2017), has been shown to be time and cost effective (Biggs et al. 2015; Boussarie et al. 2018) and can have higher detection rates compared to traditional survey methods (Hunter et al. 2015; Smart et al. 2015; Torresdal et al. 2017). However, there are challenges associated with

Marina Reyne

mreyne01@qub.ac.uk

1 School of Biological Sciences, Queen's University Belfast, Belfast BT9 5DL, UK

2 National Parks \& Wildlife Service (NPWS), 90 North King Street, Dublin 7 D07 N7CV, Ireland

3 Institute of Global Food Security (IGFS), Queen's University Belfast, Belfast BT9 5DL, UK using eDNA for biodiversity monitoring like optimisation of water collection and laboratory protocols, DNA behaviour in the environment, contamination (e.g. Buxton et al. 2017, 2018; Harper et al. 2019) that can influence DNA capture and detection.

In this study, we developed and optimized a quantitative PCR (qPCR) assay for detecting the presence of the Natterjack toad (Epidalea calamita) in water samples from breeding ponds. The species is the rarest amphibian in Ireland, regionally Red-listed as Endangered (King et al. 2011). The Natterjack toad is a subject to considerable conservation efforts including an agri-environment Pond Creation Scheme and a Head-Start and Translocation Programme by the National Parks \& Wildlife Service (NPWS) to create artificial ponds on farmland and promote colonisation (Reyne et al. 2019). The eDNA protocols developed here could be used for rapid assessment of species presence, especially for surveillance of colonisation rates of the newly created breeding sites, detecting toad presence before field signs of breeding are obvious and for monitoring post-release survival of translocated individuals (Rojahn et al. 2018).

Fieldwork was conducted in 2017 during the Natterjack toad breeding season (April-July) in Co. Kerry, Ireland (Fig. 1). We collected tadpoles and Natterjack toad tissue samples from dead individuals found in situ. DNA was preserved in $100 \%$ ethanol at ambient temperature. We collected water samples from ponds with well-known 


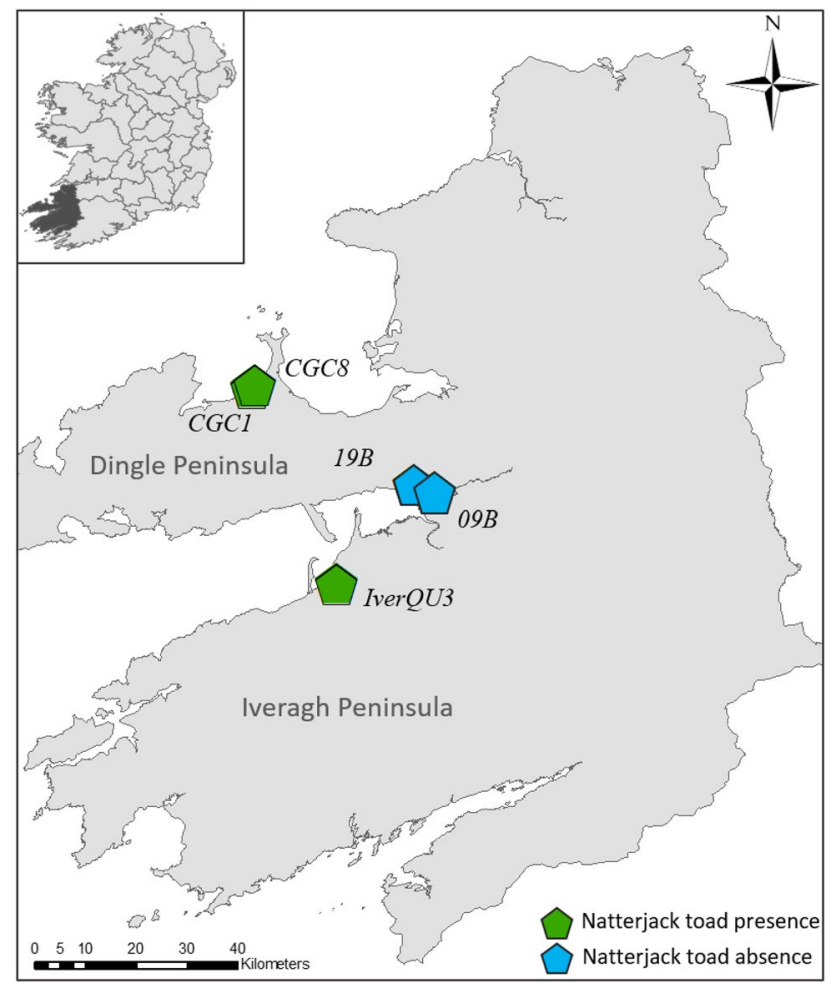

Fig. 1 Map of the study area and sampling locations of collected water samples used for qPCR assay validation

Natterjack toad presence and absence based on intensive field surveys (Bécart et al. 2007; Sweeney et al. 2013; Reyne et al. 2019). Water samples (30 mL) were collected at ten sites around the pond margin, pooled and gently mixed in a sterile self-supporting plastic bag. From each of these pooled samples, $3 \times 15 \mathrm{~mL}$ were taken with a sterile pipette and added to a $50 \mathrm{~mL}$ centrifuge tube containing $33 \mathrm{~mL} 100 \%$ ethanol and $1.5 \mathrm{~mL} 3 \mathrm{M}$ sodium acetate. A negative control of distilled water was used following the field protocol to test for cross-contamination between samples. All samples were stored at $-20{ }^{\circ} \mathrm{C}$ until extraction. Work was conducted in a UV sterilisable chamber with air ventilation. Genomic DNA was extracted using DNeasy Blood and Tissue extraction kit (Qiagen, Valencia CA, USA), while DNA extraction from water samples followed Williams et al. (2017). In summary, we used centrifugation to concentrate DNA from water, then DNA was purified using the CTAB (cetyltrimethyl ammonium bromide) protocol (Coyne et al. 2001; Turner et al. 2014), followed by a post-extraction inhibitor removal step using a OneStep PCR Inhibitor Removal kit (Zymo Inc., Irvine, California, USA).

Development of the cytochrome $c$ oxidase subunit I (COI) based qPCR assay was conducted on sequences of three individuals obtained from GenBank (accession numbers:
HM901944-47). AlleleID software version 7.5 (Premier Biosoft, USA) was used to align the COI regions, identify consensus regions and design primers. We developed an assay consisting of forward (Ecal_COI_F 5'-CCGTCAATA ACTCAATACC- $\left.3^{\prime}\right)$ and reverse (Ecal_COI_R 5'-GCAAGA ACTGGTAGAGAA-3') primers and a FAM-labelled MGB non-fluorescent quencher probe (Ecal_COI_probe 6FAM5'- AATCACTGCCGTCTTGCTTCT-3') that amplifies an 89 base pair (bp) region. After the primer design, specificity was assessed via an NCBI BLAST search (Ye et al. 2012). The assay was tested in silico against COI sequences of three European toad species (Bufo bufo, B. spinosus and Bufotes viridis) and in vitro against a panel of tissue samples of the target organism and closely related non-target species present in Ireland (the common frog Rana temporaria and smooth newt Lissotriton vulgaris) to empirically demonstrate the specificity of the developed assay. Amplification was validated via Sanger sequencing and a subsequent BLAST search on GenBank. The assay was also tested in situ on samples collected from ponds with known Natterjack toad presence and absence. We performed assay optimisation using different primer/probe concentrations and thermocycling conditions including two and three step protocols. qPCR was performed using a Magnetic Induction Cycler (MIC) platform (Bio Molecular Systems) in a final reaction volume of $20 \mu \mathrm{L}$, which included $4 \mu \mathrm{L}$ of template DNA, $10 \mu \mathrm{L}$ SensiFAST ${ }^{\mathrm{TM}}$ Probe No-ROX (Bioline

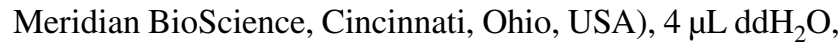
$0.8 \mu \mathrm{L}$ of each primer and $0.2 \mu \mathrm{L}$ probe. This mix was then placed into dedicated reaction tubes manufactured for MIC platform and prefilled with high viscosity silicon oil (Bio Molecular Systems) to prevent evaporation and contamination of amplicon. PCR reactions had the following thermal cycling conditions: activation step $95^{\circ} \mathrm{C}$ for $5 \mathrm{~min}$, followed by 35 cycles of $95{ }^{\circ} \mathrm{C}$ for $10 \mathrm{~s}$ and one step for annealing and extension of $60{ }^{\circ} \mathrm{C}$ for $35 \mathrm{~s}$. Tissues samples of the Natterjack toad, common frog and smooth newt were used for positive and specificity controls respectively. The results obtained from qPCR and Sanger sequencing demonstrate that the developed COI assay tested positive against only Natterjack toad tissue samples and when the species was known to be present in breeding ponds (Table 1). No amplification occurred at sites where the species was absent, or in negative controls or blanks.

The assay presented is highly specific to the Natterjack toad. We believe this method has potential to be used for species detection during monitoring and surveillance across its distribution range in Europe and for evaluating species conservation strategies including post-release survival of translocated individuals. 
Table 1 Summary of the results of the developed qPCR assay for detection presence of the Natterjack toad in eDNA samples

\begin{tabular}{lllllll}
\hline Location & Pond ID & $\begin{array}{l}\text { Natterjack } \\
\text { toad presence }\end{array}$ & Amplification & Efficiency & $\mathrm{R}^{2}$ & $\mathrm{Cq}$ \\
\hline Castlegregory Golf Course & CGC1 & Yes & Yes & 0.87 & 0.999 & 27.42 \\
Castlegregory Golf Course & CGC8 & Yes & Yes & 0.84 & 0.998 & 27.83 \\
Roscullen Island & 09B & No & No & - & - & - \\
Keel & 19B & No & No & - & - & - \\
Glenbeigh & IverQU3 & Yes & Yes & 0.79 & 0.996 & 23.64 \\
\hline
\end{tabular}

Efficiency was calculated from the gradient of a standard curve using tissue DNA and the linearity measured as $\mathrm{R}^{2}$

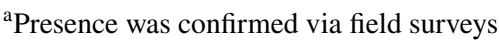

\begin{abstract}
Author contributions MR conducted field work, laboratory analysis, wrote the manuscript. AN provided guidelines on laboratory procedures including primer development, qPCR optimization and interpretation of results. FM substantially contributed to revising the manuscript. NR contributed throughout from conception, methodology, and fieldwork to manuscript editing. SH was the Principal Investigator, supervised the molecular work and analysis of genetic data contributing throughout from conception, methodology, and data analysis to manuscript editing. All authors discussed the results, contributed to the draft, read the final manuscript and gave approval for publication.
\end{abstract}

Funding National Parks \& Wildlife Service (NPWS), Department of Culture, Heritage and the Gaeltacht, Republic of Ireland.

\section{Data availability NA.}

Code availability No custom codes were used.

\section{Declarations}

Conflict of interest The authors declare that they have no conflict of interest.

Ethical approval All samples were collected under license to capture protected wildlife animals Licence No. C098/2016 issued by the National Parks \& Wildlife Service (NPWS), Department of Culture, Heritage and the Gaeltacht, Republic of Ireland. Tissue samples were collected only from already dead individuals.

Consent to participate/consent of publication NA (no human participants in the study).

\section{Clinical trials registration NA.}

\section{Gels and blots/image manipulation NA.}

Open Access This article is licensed under a Creative Commons Attribution 4.0 International License, which permits use, sharing, adaptation, distribution and reproduction in any medium or format, as long as you give appropriate credit to the original author(s) and the source, provide a link to the Creative Commons licence, and indicate if changes were made. The images or other third party material in this article are included in the article's Creative Commons licence, unless indicated otherwise in a credit line to the material. If material is not included in the article's Creative Commons licence and your intended use is not permitted by statutory regulation or exceeds the permitted use, you will need to obtain permission directly from the copyright holder. To view a copy of this licence, visit http://creativecommons.org/licenses/by/4.0/.

\section{References}

Bécart E, Aubry A, Emmerson M (2007) Monitoring the conservation status of Natterjack Toad (Bufo calamita) in Ireland, 2004-2006 Irish Wildlife Manuals. No 31 National Parks and Wildlife Service Department of the Environment, Heritage and Local Government, Dublin, Ireland

Biggs J, Ewald N, Valentini A, Gaboriaud C, Dejean T, Griffiths RA, Foster J, Wilkinson JW, Arnell A, Brotherton P, Williams P, Dunn $F$ (2015) Using eDNA to develop a national citizen science-based monitoring programme for the great crested newt (Triturus cristatus). Biol Conserv 183:19-28

Boussarie G, Bakker J, Wangensteen OS, Mariani S, Bonnin L, Juhel JB, Kiszka JJ, Kulbicki M, Manel S, Robbins WD, Vigliola L, Mouillot D (2018) Environmental DNA illuminates the dark diversity of sharks. Sci Adv 4:eaap9661

Buxton AS, Groombridge JJ, Griffiths RA (2017) Is the detection of aquatic environmental DNA influenced by substrate type? PLoS One 12(8):e 0183371

Buxton A, Groombridge J, Griffiths R (2018) Comparison of two citizen scientist methods for collecting pond water samples for environmental DNA studies. Citiz Sci Theory Pract 3(2):2

Coyne KJ, Hutchins DA, Hare CE, Cary SC (2001) Assessing temporal and spatial variability in Pfiesteria piscicida distributions using molecular probing techniques. Aquat Microb Ecol 24(3):275-285

Deiner K, Bik HM, Mächler E, Seymour M, Lacoursière-Roussel A, Altermatt F, Creer S, Bista I, Lodge DM, de Vere N, Pfrender ME, Bernatchez L (2017) Environmental DNA metabarcoding: transforming how we survey animal and plant communities. Mol Ecol 26:5872-5895

Dougherty MM, Larson ER, Renshaw MA, Gantz CA (2016) Environmental DNA (eDNA) detects the invasive rusty crayfish Orconectas rusticus at low abundances. J Appl Ecol 53:722-732

Harper LR, Buxton AS, Rees HC, Bruce K, Brys R, Halfmaerten D, Read DS, Watson HV, Sayer CD, Jones EP, Priestley V, Mächler E, Mrria C, Garces-Pastor S, Medupin C, Burgess K, Benson G, Boonham N, Griffiths RA, Handley LL, Hänfling B (2019) Prospects and challenges of environmental DNA (eDNA) monitoring in freshwater ponds. Hydrobiologia 826:25-41

Hunter ME, Oyler-McCance SJ, Dorazio RM, Fike JA, Smith BJ, Hunter CT, Reed RN, Hart KM (2015) Environmental DNA (eDNA) sampling improves occurrence and detection estimates of invasive Burmese pythons. PLoS One 10(4):e0121655 
King JL, Marnell F, Kingsto, N, Rosell R, Boylan P, Caffrey JM, FitzPatrick Ú, Gargan PG, Kelly FL, O'Grady MF, Poole R, Roche WK, Cassidy D (2011) Ireland Red List No. 5: amphibians, reptiles \& freshwater fish. National Parks and Wildlife Service, Department of Arts, Heritage and the Gaeltacht, Dublin, Ireland

Laramie MB, Pilliod DS, Goldberg CS (2015) Characterizing the distribution of an endangered salmonid using environmental DNA analysis. Biol Conserv 138:29-37

Ma H, Stewart K, Lougheed S, Zheng J, Wang Y, Zhao J (2016) Characterization, optimization, and validation of environmental DNA (eDNA) markers to detect and endangered aquatic mammal. Conserv Genet Resour 8:561-568

Mazerolle MJ, Bailey LL, Kendall WL, Royle JA, Converse SJ, Nicholas JD (2007) Making great leaps forward: accounting for detectability in herpetological field studies. J Herpetol 41:672-689

Reyne M, Aubry A, Martin Y, Helyar S, Emmerson M, Reid N (2019) Natterjack toad (Epidalea calamita) monitoring and conservation status 2016-2018 Irish Wildlife Manual No 107 National Parks and Wildlife Service, Department of Culture, Heritage and the Gaeltacht, Dublin, Ireland

Rojahn J, Gleeson D, Furlan EM (2018) Monitoring post-release survival of the northern corroboree frog, Pseudophryne pengilleyi, using environmental DNA. Wildl Res 45:620-626

Smart AS, Tingley R, Weeks AR, van Rooyen AR, McCarthy MA (2015) Environmental DNA sampling is more sensitive than a traditional survey technique for detecting aquatic invader. Ecol Appl 25:1944-1952
Sweeney P, Sweeney N, Hurley C (2013) Natterjack Toad monitoring project, 2011-2012 Irish Wildlife Manuals. No 67 National Parks and Wildlife Service, Department of Arts, Heritage and the Gaeltacht, Dublin, Ireland

Torresdal JD, Farrell AD, Goldberg CS (2017) Environmental DNA detection of the Golden Tree frog (Phytotriades auratus) in Bromeliads. PLoS One 1:e0168787

Turner CR, Miller DJ, Coyne KJ, Corush J (2014) Improved methods for capture, extraction and quantitative assay of environmental DNA from Asian Bigheaded carp. PLoS One 9(12):e114329

Vörös J, Márton O, Schmidt BR, Gál JT, Jelić D (2017) Surveying Europe's only cave-dwelling chordate species (Proteus anguinus) using environmental DNA. PLoS One 12(1):e0170945

Williams KE, Huyvaert KP, Piaggio AJ (2017) Clearing muddied waters: capture of environmental DNA from turbid waters. PLoS One 7:1-17

Ye J, Coulouris G, Zaretskaya I, Cutcutache I, Rozen S, Madden TL (2012) Primer-BLAST: a tool to design target-specific primers for polymerase chain reaction. BMC Bioinform 13:134

Publisher's Note Springer Nature remains neutral with regard to jurisdictional claims in published maps and institutional affiliations. 